\title{
EFFECT OF CUTTING EDGE GEOMETRY ON CUTTING TOOL LIFE WHEN DRILLING INCONEL 718
}

\author{
Milan Daňa, Miroslav Zetek, Václav Schorník \\ Regional Technological Institute, University of West Bohemia - Faculty of Mechanical Engineeering, \\ Univerzitní 8, Pilsen 30614
}

\begin{abstract}
This work deals with the problematics of drilling holes in Inconel 718. This material has found applications especially in the aerospace industry and in other demanding applications due to its characteristic properties. Its special properties are high strength at high temperatures, corrosion resistance, low thermal conductivity, high hardness and work hardening. Even using modern technologies, the machining of this material is a problem. These problems are partially described in this paper. The drilling of this material is a topical subject and therefore modern approaches are used for this operation. This paper is limited only to carbide tools. The second part of the paper is focused on the experiment where the effects of the geometry of the cutting edge on cutting tool life are evaluated. The results of the experiment are compared with results from other research institutes.
\end{abstract}

Keywords: Drilling; Cutting tool life; Cutting forces; Inconel 718
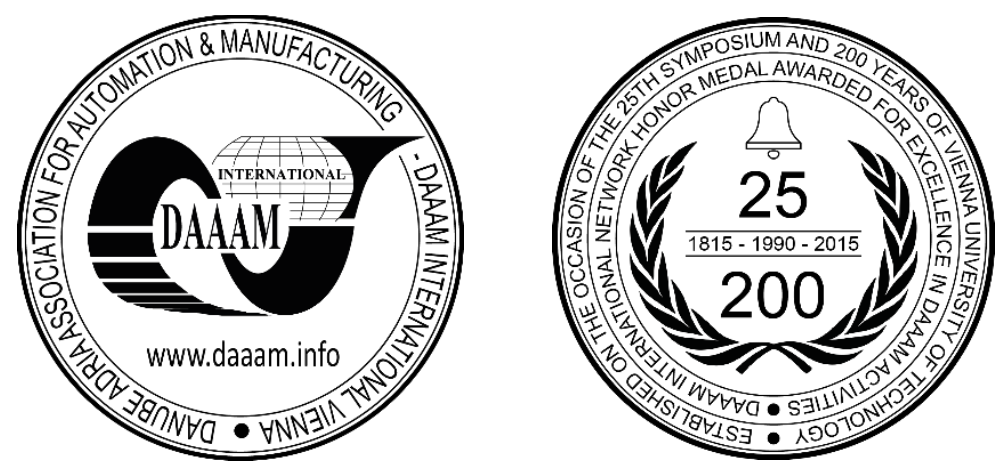

This Publication has to be referred as: Dana, M[ilan]; Zetek, M[Iroslav] \& Schorník, V[aclav] (2016). Effect of Cutting Edge Geometry on Cutting Tool Life when Drilling Inconel 718, Proceedings of the 26th DAAAM International Symposium, pp.0709-0714, B. Katalinic (Ed.), Published by DAAAM International, ISBN 978-3-902734-07-5, ISSN 1726-9679, Vienna, Austria

DOI: $10.2507 / 26$ th.daaam.proceedings.098 


\section{Introduction}

Inconel 718 was developed during the last century. This material is located in a group of difficult to machine materials because machining of this material using common methods is very difficult. Materials such as Inconel 718 have high strength, high hardness, low heat conductivity, corrosion resistance, high strength at high temperature and many other unique properties. This material has found applications primarily in aerospace due to its special features. Given that Inconel 718 is used in important sectors, it is necessary to deal with the machining of this material. Machining of this material is a very big problem even today using the most modern technologies. This paper deals with a strategy of machining called drilling. Drilling covers a very wide range and this paper is limited to only monolithic drills. Almost every part situated in a spaceship or a plane contains at least one or several holes. Reference [1] also focuses on drilling this material using a newly designed drill. This drill achieved great results in comparison with reputable producers. This reference contains very interesting information concerning this issue. Reference [2] provides much information about the geometries of the drills which are suitable for Inconel 718. The information from this reference was used for designing the experiment. Reference [3] is a very substantial paper containing an extensive description of types of wear of monolith drills. References [4] and [5] give information about the machinability of Inconel 718 and its material properties which are essential for productive machining. The paper [9] describes in detail the problems which occur when drilling Inconel 718. The paper also deals with a special modification to the flank of the tool which increased the cutting tool life.

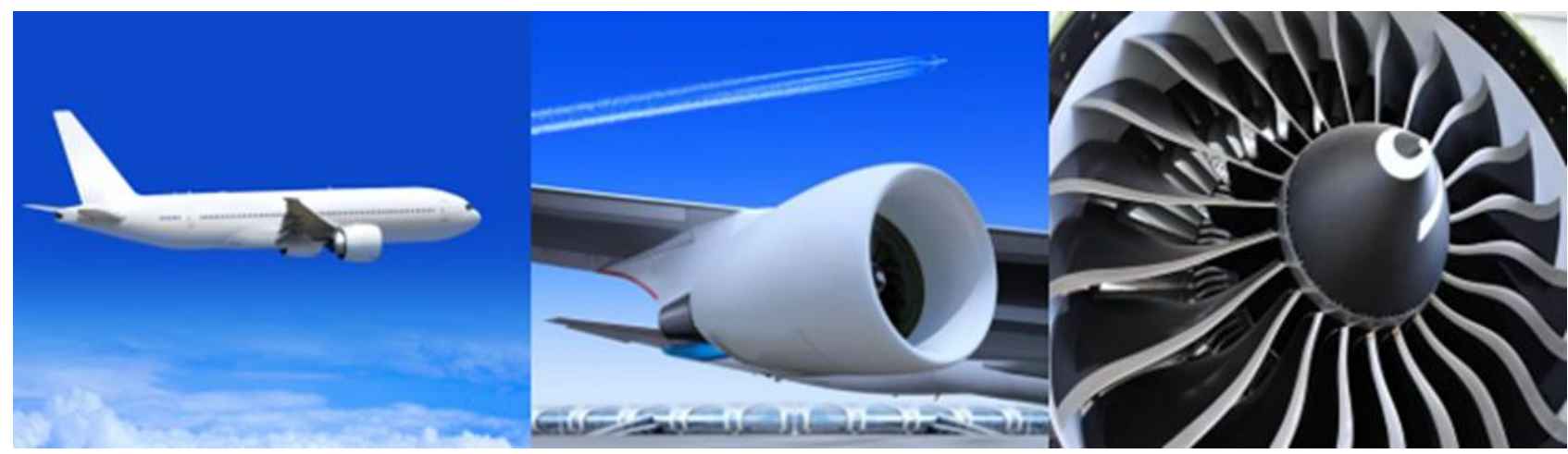

Fig. 1. Uses of Inconel 718 [7]

\section{Material properties}

Inconel 718 is known thanks to the company Special Metals Corporation which supplies specialist materials to the world market. Inconel is a very frequently used material in this group of specialist materials. We can find this material under the designation UNS N07718, W.Nr. 2.4668, but most often under its tradename. This alloy belongs to the nickelbased alloys, which are characterized by their high content of nickel - about 50\%. Inconel 718 has special properties which common materials cannot achieve. The special properties are for example strength at high and low temperatures. It can withstand temperatures from $-250^{\circ} \mathrm{C}$ up to $+700^{\circ} \mathrm{C}$. Another unique property is corrosion resistance at high temperature. A surface layer of oxide is created during heating to high temperature on the surface of a part. This surface layer of oxide protects the component against hostile influences. The hardness of this material is dependent on the heat treatment. The hardness can be $20-25 \mathrm{HRC}$ in the annealed condition, but the hardness can be $36-44 \mathrm{HRC}$ after hardening. Ultimate tensile strength reaches values up $1300 \mathrm{MPa}$. [10],[17]

\section{Machinability of Inconel 718}

The machinability of Inconel 718 is very hard and cutting tool wear is high. It belongs to a group of materials which is the most difficult for machining. The materials in this group are for example Rene, Waspaloy, Nimonic and so on. These alloys are very difficult to machine due to their excellent mechanical properties. Inconel 718 has a basic property during machining and this is hardening. Mechanical hardening is created during the contact of the cutting tool with the machined part. It is necessary to limit the machining to the smallest possible number of operating cycles. It is recommended to set the cutting edge of the tool deeper than the thickness of the hardened layer. During the machining of this alloy a large amount of heat is generated due to poor thermal conductivity. This means it is appropriate to use cooling. The cooling ensures better heat dissipation from the cutting area. The cooling is done using a high pressure and high volume of coolant. [1],[8],[13],[17] 


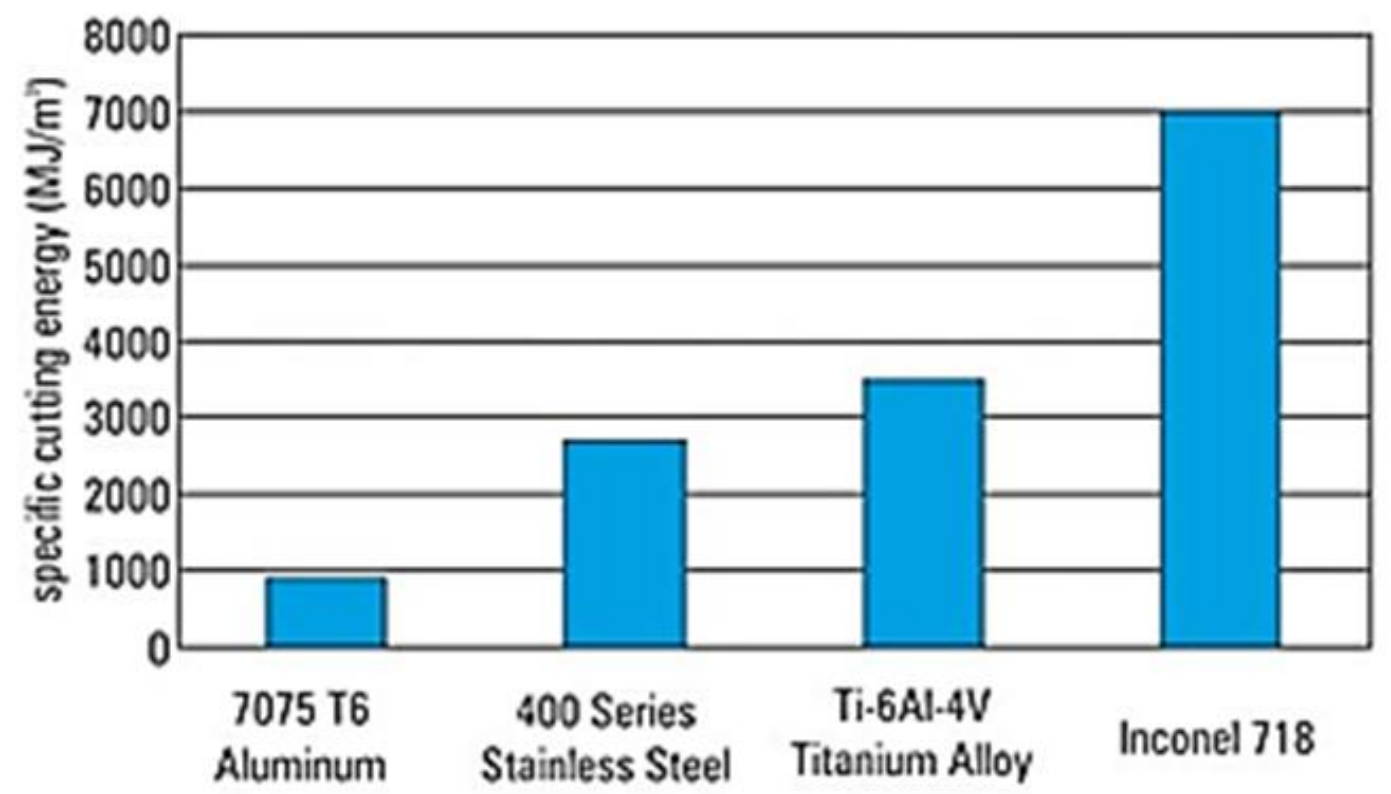

Fig. 2. Machinability of Inconel 718 [14].

\section{Problems when machining}

Drilling is a very difficult operation because it has certain specifics which are unlike milling and turning. The major differences are a variable cutting speed along the main cutting edge, more difficult chip evacuation and the bad access of liquids into the cutting area. Drilling of Inconel 718 is characterized by a great number of problems. These problems are described below. [1],[15]

During the drilling of Inconel the temperature increases in the cutting area. The temperature may reach up to $1200^{\circ} \mathrm{C}$. A popular method of drilling is drilling with ultrasonic assistance. This method achieves a lower temperature in the cutting area. [6] Another undesitrable property is associated with the temperature. The ductility increases with the increasing temperature. For example, the ductility at $800^{\circ} \mathrm{C}$ is approximately $30 \%$. This causes difficulties during chip separation. A built up edge is very often formed during the drilling of this material. Stainless steel is also characterized by the creation of a built up edge. The problems are similar when machining Inconel and stainless steel. The safety of drilling is a very important factor due to the cost of machining a part. Large tool overhangs lead to dangerous drilling. The tool overhang should be selected considering the hole depth and chip removal. [1],[3],[16]

\section{The geometry of drills}

Twist drills are tools with a very complicated shape. A certain type of geometry is used for productive machining of a particular type of material, therefore there are many types of geometry. Twist drills with suitable geometries for Inconel 718 are shown in Fig.3.
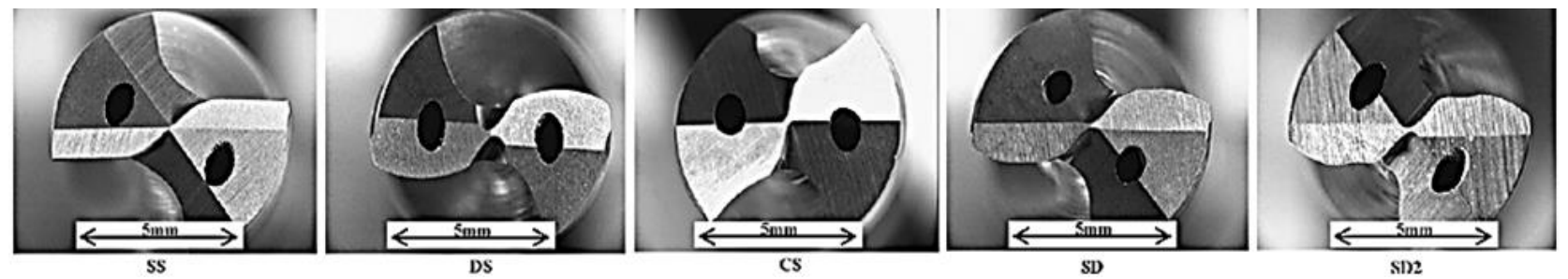

Fig. 3. Geometries of drills used for Inconel 718 [2]

The transverse edge of a drill is not suitable for drilling this type of material as stress accumulates on the transverse edge of the drill. The cutting tool life was increased by reduction of the transverse edge of the drill. This tool life was increased up to several times as stated in reference [2]. 


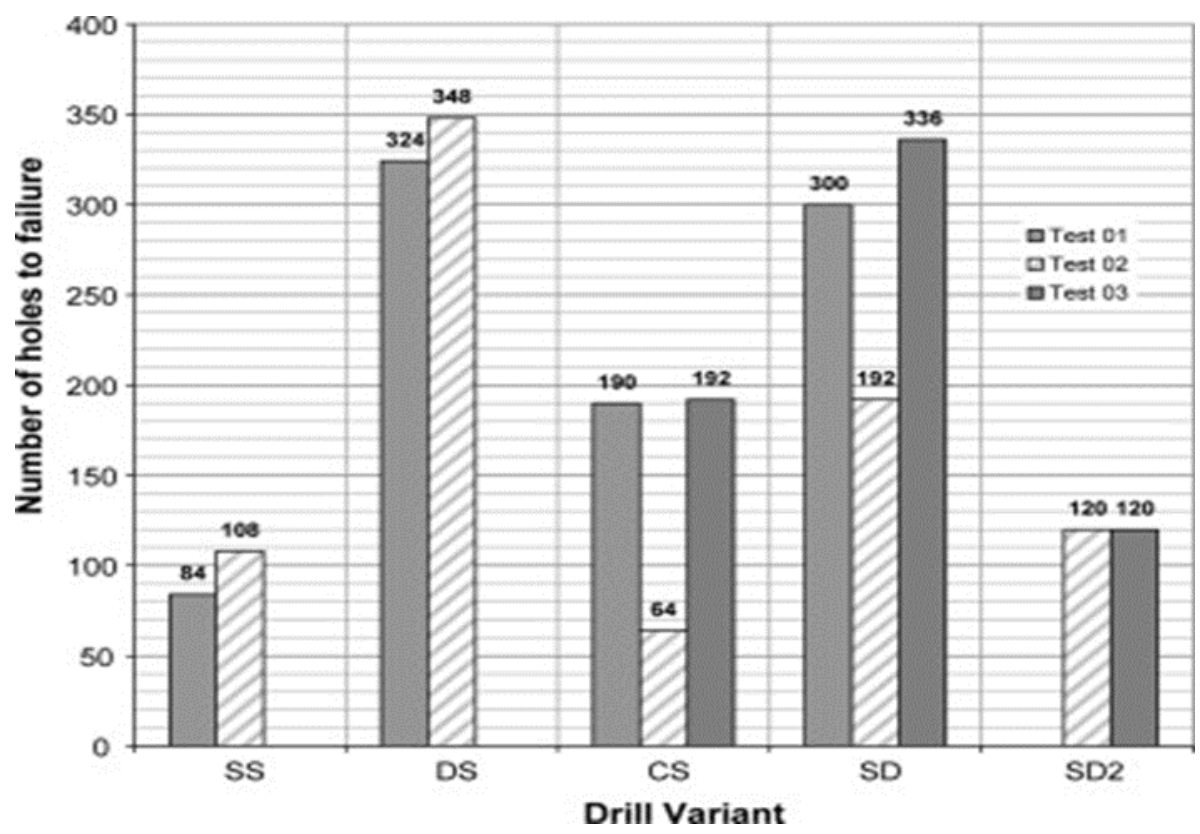

Fig. 4. The comparison of tool life [2]

\section{Experiment}

Twist drills with geometries SS and SD were selected for this experiment. These drills were selected to confirm or refute the results from reference [2]. The drill with geometry SS achieved the shortest tool life. The drill with geometry SD achieved the second longest tool life. The selected drills are the subject of the practical part of this experiment.
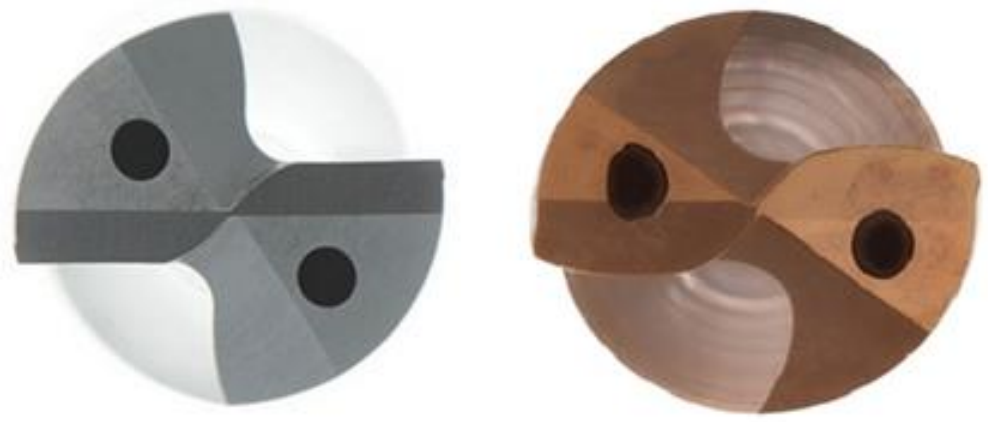

Fig. 5. The geometries used for the experiment [11],[12].

The drills were selected with diameter $12 \mathrm{~mm}$ and cutting length 3D. The cutting conditions were set according to the manufacturer's recommendations and catalogue values. The cutting conditions were constant throughout the experiment. The cutting conditions were as follows: cutting speed $\mathrm{v}_{\mathrm{c}}=22 \mathrm{~m} / \mathrm{min}$ and feed per rotation $\mathrm{f}_{\mathrm{ot}}=0.19 \mathrm{~mm}$. The pressure of internal cooling was set at $p=2 \mathrm{MPa}$. Criteria value of experimental machining vas set on $150 \mu \mathrm{m}$ of tool wear. All samples had the same material and mechanical properties. The material and mechanical properties are listed in the following tables. The chemical composition is given for individual elements in percent.

\begin{tabular}{ccccccccccccccc}
\hline $\mathrm{Ni}$ & $\mathrm{Cr}$ & $\mathrm{Fe}$ & $\mathrm{Nb}(+\mathrm{Ta})$ & $\mathrm{Mo}$ & $\mathrm{Ti}$ & $\mathrm{Al}$ & $\mathrm{Co}$ & $\mathrm{Mg}$ & $\mathrm{Si}$ & $\mathrm{Cu}$ & $\mathrm{C}$ & $\mathrm{P}$ & $\mathrm{S}$ & $\mathrm{B}$ \\
\hline 53.15 & 18.5 & 18.53 & 4.936 & 2.84 & 1.06 & 0.49 & 0.02 & 0.08 & 0.14 & 0.02 & 0.024 & 0.009 & 0.001 & 0.0028 \\
\hline
\end{tabular}

Table 1. The material composition.

\begin{tabular}{ccccccc}
\hline $\begin{array}{c}\text { Yield strength Rp0,2 } \\
\text { in MPa }\end{array}$ & $\begin{array}{c}\text { Strength Rm } \\
\text { in MPa }\end{array}$ & $\begin{array}{c}\text { Ductility A4 } \\
\text { in \% }\end{array}$ & $\begin{array}{c}\text { Contraction Z } \\
\text { in \% }\end{array}$ & $\begin{array}{c}\text { Hardness } \\
\text { in HB }\end{array}$ & $\begin{array}{c}\text { Deformation work } \\
\text { in J }\end{array}$ & $\begin{array}{c}\text { Heat conductivity } \\
\text { in W/mK }\end{array}$ \\
\hline 938 & 1227 & 27 & 4.936 & 355 & 1.06 & 11 \\
\hline
\end{tabular}

Table 2. The material properties 


\section{Results}

This section is focused on evaluation of the cutting tool life and examples of wear. The length of the drill hole was selected as the criterion for cutting tool life. A large number of results were obtained from the experiment. The tool wear was not linear. Experimental measuring was always stopped because of reaching broken the cutting tool edge. The results were plotted in a simple graph, which shows the cutting tool life and wear of the tool. In Fig. 6 can be seen the result of the experiment, which does not confirm the results from reference [2].

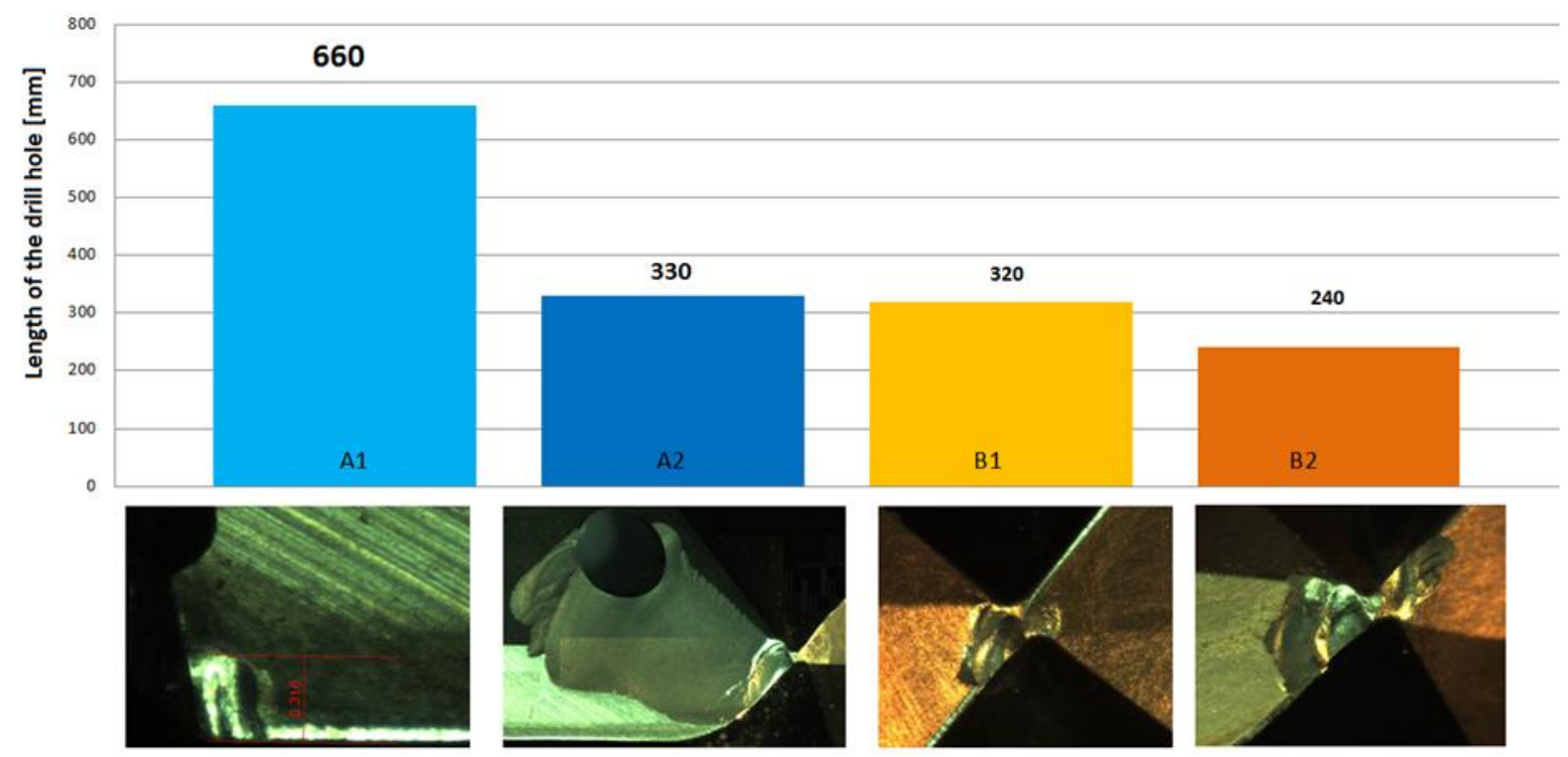

Fig. 6. The results

\section{Conclusion}

This paper presents results in terms cutting tool life, when drilling Inconel 718. The experiment when Inconel 718 was machined with twist drills was carried out. The experiment shows the value of the tool wear under the same cutting conditions. Tool A1 with geometry SS achieved the longest tool life. The tool life of tool A1 reached 660mm. Wear occurred on the tool tip. The confirmation drill A2 achieved only half the tool life of A1. The wear of this drill had a different character, as you can see in Fig.6. The wear was situated at a different place on the cutting edge. Drill B1 achieved a tool life of $320 \mathrm{~mm}$ and it was confirmed by drill B2 with only $240 \mathrm{~mm}$. Both drills showed the same type of wear, i.e. wear on the chisel edge. Results show how it is very important when machining Inconel 718 to choose a correct tool with correct tool geometry.

It may be stated that the results from reference [2] and the results from our experiment are different. The drill with SS geometry achieved a longer cutting tool life than the drill with SD geometry. These differences may be caused by for example: the difference between diameters, difference between cutting conditions, or the difference between chemical and mechanical properties of materials.

The drilling of Inconel 718 is a very demanding technological operation, therefore it is necessary to carry out further research in the field. It is necessary to look for the suitable interplay of cutting conditions which have a major impact on the cutting tool life.

\section{Acknowledgements}

This paper is based upon work sponsored by project the "Regionální technologický institut" no. CZ.1.05/2.1.00/03.0093 and project SGS-2013-031.

\section{References}

[1] KOŽMÍN, P. KŘÍŽ, A. ROUD, P. Drilling holes with increased accuracy. MM Industrial Spectrum 2011. number. 5 Available from: http://www.mmspektrum.com/clanek/vrtani-der-se-zvysenou-presnosti.html

[2] A.R.C. Sharman, A. Amarasinghe, K. Ridgway. Tool life and surface integrity aspects when drilling and Hole making in Inconel 718. [cit. 2015-05-19]. United Kingdom 2007. Journal of Materials ProcessingTechnology,Volume 200, Issues 1-3, 8 May 2008, Pages 424-432 available from: http://www.sciencedirect.com/science/article/pii/S0924013607008382

[3] Y.C. Chen, Y.S. Liao. Study on wear mechanisms in drilling of Inconel 718 superalloy. [cit. 2015-05-19]. Journal of Materials Processing Technology, Volume 140, Issues 1-3, 22 September 2003, Pages 269-273, Proceedings of 
the 6th Asia Pacific Conference on materials Processing. available from: http://www.sciencedirect.com/science/article/pii/S0924013603007921

[4] M. Rahman, W.K.H. Seah, T.T. Teo. The machinability of Inconel 718. [cit. 2015-05-19]. Journal of Materials Processing Technology, 63 (1997), Pages 199-204, available from: http://ac.els-cdn.com/S0924013696026246/1s2.0-S0924013696026246-main.pdf?_tid=4c13827a-401d-11e5-93b000000aacb360\&acdnat $=1439293208 \_96101 \mathrm{f} 963300110 \mathrm{fadc} 3389 \mathrm{c} 09 \mathrm{df} 67 \mathrm{a} 4$

[5] I.A. Choudhury, M.A. El-Baradie, Machinability of nickel-base super alloys: a general view, J. Mater. Process. Technol. 77 (1998) 278-284. available from: http://www.sciencedirect.com/science/article/pii/S0924013697004299

[6] Celaya, A; Pujana, J; Lopez De Lacalle, L N; Rivero, A \& Campa, F J (2008). Improvement of Turning and Drilling by Ultrasonic Assistance, Chapter 18 in DAAAM International Scientific Book 2008, pp. 205-218, B. Katalinic (Ed.), Published by DAAAM International, ISBN 978-3-901509-66-7,ISSN 1726-9687, Vienna, Austria

[7] Polymet. Aerospace. [cit. 2015-07-19] Available from: http://www.polymet.us/markets-applications/aerospace

[8] DONACHIE, M. J., DONACHIE, S. J.: Superalloys - A Technical Guide, Materials Park :ASM International,2002. 2nd ed. $\mathrm{x}, 437$ s. ISBN 0-87170- 749-7

[9] Nicolas Beer, Ekrem Özkaya, Dirk Biermann. Drilling of Inconel 718 with geometry-modified twist drills [cit. 2015 07-25] Procedia CIRP Volume 24, Pages 49 - 55. New Production Technologies in Aerospace Industry - 5th Machining Innovations Conference (MIC 2014). from: http://www.sciencedirect.com/science/article/pii/S2212827114009378\#

[10] Special Metals Corporation, High-Performance Alloys for Resistance to Aqueous Corrosion, [cit. 2015-07-09] available from: http://www.parrinst.com/wp-content/uploads/downloads/2011/07/Parr_Inconel-Incoloy-MonelNickel-Corrosion-Info.pdf

[11] SANDVIK COROMANT. Vrták R846 [cit. 2015-07-23]. Available from: http://www.amazon.com/SandvikCoromant-CoroDrill-Delta-C-Multilayer/dp/B005FXF0JS

[12] OSG Tools. EXOPRO® WHO-Ni Drills [cit. 2015-07-23]. available from: http://www.osgtool.com/c5950Ni.htm

[13] SLABÝ, O. Technology of rotary Inconel element manufacturing in Frencken Brno. In Brno, 2009. available from: https://www.vutbr.cz/www_base/zav_prace_soubor_verejne.php?file_id=17059. Brno University of technology

[14] PLATIT, Comparison of Machinability of Different Workpiece Materials, [cit. 2015-02-23]. Available from: http://www.platit.com/coating-features

[15] Anghel, C.; Petropoulos, G.; Vaxevanidis, N. \& Dasic, P. (2008). Statistical Modeling of Basic Machinability Parameters in Drilling of Metals, Annals of DAAAM for 2008 \& Proceedings of the 19th International DAAAM Symposium, 22-25th October 2008, Trnava, Slovakia, ISSN 1726-9679, ISBN 978-3-901509-68-1, Katalinic, B. (Ed.), pp. 0021-0022, Published by DAAAM International Vienna, Vienna

[16] JURKO, J \& PANDA, A. Study of machinability of elc stainless steel x2cr20ni10moti and accompanying phenomena in the cutting zone during drilling. Annals of DAAAM for 2011 \& Proceedings of the 22nd International DAAAM Symposium, Volume 22, No. 1, ISSN 1726 - 9679 ISBN 978-3-901509-83-4, Editor B. Katalinic, Published by DAAAM International, Vienna, Austria, EU, 2011

[17] SCHORNÍK, V., ZETEK, M., DAŇA, M. The influence of working environment and cutting conditions on milling nickel ? based super alloys with carbide tools. In Procedia Engineering. Vídeň: DAAAM International Vienna, 2015. s. 1262-1269. ISBN: 978-3-901509-99-5 , ISSN: 1877-7058

[18] ZETEK, M., ČESÁKOVÁ, I., ŠVARC, V. Increasing cutting tool life when machining Inconel 718. In Collection of Working Papers for 24th DAAAM International Symposium. Vienna: DAAAM International, 2013. s. 1-6. ISBN: 978-3-901509-97-1 , ISSN: 1877-7058 